\title{
Going beyond Cryptocurrencies: The Social Representation of Blockchain
}

\author{
Luiz Antonio Joia *(1) and Juliana Aparecida Pinto Vieira
}

check for

updates

Citation: Joia, L.A.; Vieira, J.A.P. Going beyond Cryptocurrencies: The Social Representation of Blockchain. Sustainability 2021, 13, 14054. https://doi.org/10.3390/su132414054

Academic Editor: Cheolho Yoon

Received: 16 November 2021 Accepted: 14 December 2021 Published: 20 December 2021

Publisher's Note: MDPI stays neutral with regard to jurisdictional claims in published maps and institutional affiliations.

Copyright: (c) 2021 by the authors. Licensee MDPI, Basel, Switzerland. This article is an open access article distributed under the terms and conditions of the Creative Commons Attribution (CC BY) license (https:// creativecommons.org/licenses/by/ $4.0 /)$.
Brazilian School of Public and Business Administration, Getulio Vargas Foundation, Rio de Janeiro 22231-010, Brazil; professora.julianav@gmail.com

* Correspondence: luiz.joia@fgv.br

Abstract: This study investigates the social representation of Blockchain from the perspective of professionals in Brazil, herein considered as a proxy for emerging markets, and then compares the results found with the existing academic literature on the concept of Blockchain. To do that, the social representation theory was applied, operationalized through the words evocation technique. Security, bitcoin and decentralization were the categories located in the central nucleus of the social representation of Blockchain, while innovation, data, network, cryptocurrency, and technology were the categories located in the peripheral system. Based on the results obtained, there was a perceived strong association of Blockchain with bitcoin, one of its applications, and a dissonance between the existing academic literature and the perception of Brazilian professionals about the concept of Blockchain, as the latter is a privilege of the technical and operational issues of Blockchain to the detriment of its strategic potential. This dissonance can cause Blockchain initiatives to have results below expectations. Finally, Brazilian professionals did not realize the potential for inclusion of Blockchain in an emerging market such as Brazil and did not notice the need and relevance of a specific legal governance for Blockchain, an issue also forgotten by academia.

Keywords: Blockchain; social representation theory; words evocation technique; constructs definition

\section{Introduction}

Blockchain became known worldwide from 2008 onwards with the publication of an article written by an author under the pseudonym of Satoshi Nakamoto and the ensuing advent of the bitcoin cryptocurrency [1]. Despite having emerged to control bitcoin transactions, Blockchain is not restricted to this area [2]. In fact, after a few years of success due to bitcoin, other sectors have shown interest in expanding the range of use of Blockchain, making it an alternative to ledgers [3,4]. Indeed, Blockchain is responsible for providing security to data storage and exchange flow, without the intermediation of a "central entity", working as a validator of this process and being able to prove when and by whom the data was generated, which leads to impossibility of frauds [5]. Thus, Wright and De Filipe [6] point out that for the first time it is possible for strangers to reach a consensus on the execution of transactions without the interference or validation of a "central entity". This feature has the potential to reduce the importance of regulatory actors, as it decentralizes the storage and management of information.

Among the several possible applications of Blockchain, one can mention: self-executing digital contracts (smart contracts), new governance systems, asset registers of different natures, and public registries, to name just a few [4-6]. However, despite the importance of Blockchain, there is a notorious difficulty in clearly defining it, which makes it a polysemic concept $[7,8]$. In other words, a question remains regarding the concept of Blockchain per se [9]. Is this concept independent of the context where it is implemented? In other words, what is the perception of professionals in emerging markets [10] regarding this construct? Do they perceive Blockchain as the construct that has been portrayed in the existing literature produced by academia in developed countries? 
Based on that, this work intends to answer the following research question: What is the social representation of Blockchain according to Brazilian professionals involved with it? Therefore, through social representation theory (SRT), this research aims to identify the elements belonging to the central nucleus and the peripheral system of the social representation of Blockchain from the perspective of Brazilian professionals who are somehow familiar with this technological paradigm. In addition, this work aims to compare the existing scientific literature on the concept of Blockchain with the perception of Brazilian professionals on the subject in order to verify whether there is dissonance between these two groups.

The option for the Brazilian context in this research is justified by the very fact that Brazil is one of the leading countries in the world in IT spending and represents about half of the total IT spending in Latin America. Besides, as Blockchain has evolved as a dominant technological paradigm in recent years, most organizations in Brazil have developed and used Blockchain applications both in the private sector [11,12] and in the public sector $[12,13]$. Thus, in this work, Brazil is considered a proxy for emerging markets that are taking advantage of Blockchain.

Furthermore, as most research on the Blockchain concept has been carried out in developed countries [14], it is important to verify whether this literature has taken into account the context found in developing countries and whether it really reflects the potential of Blockchain to generate inclusion in these nations, in line with the Sustainable Development Goals of the United Nations [15-17].

\subsection{Theoretical Background}

\subsubsection{Blockchain}

As already mentioned, the concept of Blockchain emerged in 2008 through an article written by an author under the pseudonym Satoshi Nakamoto [18]. In that article, the author proposed a decentralized technological system, called timestamp and, later, Blockchain, to prevent a cryptocurrency transaction from suffering double-spending-a potential vulnerability of bitcoin transactions associated with the duplication of transacted values, that is, the use of the same payment unit in different transactions [19].

The system created by Nakamoto is a combination of several other systems developed previously, such as b-money and HashCash, which also aimed to create a decentralized system capable of validating transactions without the need for a central authority to legitimize the process. These systems, however, did not resolve the issue of double spending [18,20].

By mistake, the terms Blockchain and bitcoin have often been confused [21]. However, bitcoin represents only one of several possible applications allowed by Blockchain [22]. In other words, Blockchain represents the technology underlying bitcoin, i.e., it is the platform on which bitcoin is built [1]. According to Lakomski-Laguerre and Desmedt [23], the innovation brought about by the advent of the bitcoin cryptocurrency does not reside in the currency itself but in its payment system, which enables the execution of financial transactions without a central regulatory agent, that is, the innovation associated with bitcoin resides in Blockchain. In fact, for Yli-Huumo et al. [3], data integrity without any third-party intervention, anonymity, and security are the strengths of Blockchain, which has aroused interest in several sectors and companies. Blundell-Wignall [24] states that the absence of an intermediary that holds the entire repository of data records associated with a trade drastically reduces transaction costs, which is one of the main advantages of Blockchain.

In scientific literature, Blockchain is presented in different ways and as having different possibilities of application in the real world. Table 1 presents the different approaches associated with this issue in order to show the plurality of concepts associated with Blockchain.

Besides, Table 2 gathers the main features of Blockchain, according to the perspective of different academics. 
Table 1. Summary of the concepts of Blockchain.

\begin{tabular}{|c|c|c|}
\hline Item & Concepts of Blockchain & References \\
\hline 1 & $\begin{array}{l}\text { Blockchain is a chain of blocks where each block contains information. More specifically, this term is } \\
\text { used to identify a type of database distributed in a network with several participants, in which there } \\
\text { is no central controlling entity and where no participant is more reliable than the other, therefore } \\
\text { depending on a decentralized consensus. }\end{array}$ & [25] \\
\hline 2 & Blockchain is a chain of blocks joined by hashes. & [26] \\
\hline 3 & $\begin{array}{l}\text { Blockchain is a distributed ledger that represents the consensus of every operation that took place } \\
\text { on the network. }\end{array}$ & [1] \\
\hline 4 & $\begin{array}{l}\text { Blockchain is a database for storing transactions that are shared between all parties on a network. It } \\
\text { serves as a (encrypted) ledger for information. }\end{array}$ & [27] \\
\hline 5 & $\begin{array}{l}\text { Blockchain is a secure business network in which participants transfer items of value (assets) through } \\
\text { a common distributed ledger, which each participant has a copy of, and with the content in constant } \\
\text { synchronicity with the others. }\end{array}$ & [28] \\
\hline 6 & $\begin{array}{l}\text { Blockchain is a shared and distributed ledger that facilitates the process of recording transactions and } \\
\text { tracking assets in a commercial network. }\end{array}$ & [29] \\
\hline 7 & $\begin{array}{l}\text { Blockchain is a public distributed online database that can be updated by any node participating in } \\
\text { the peer-to-peer (P2P) network. This update is based on consensus between the nodes, being } \\
\text { guaranteed by a proof-of-work algorithm that has as the main objective of hindering cyber-attacks. }\end{array}$ & [30] \\
\hline 8 & Blockchain is a distributed transactional database spread across different nodes of a network. & [31] \\
\hline 9 & Blockchain is a list of validated blocks, each linked to its predecessor, until reaching the genesis block. & [20] \\
\hline 10 & $\begin{array}{l}\text { Blockchain is a distributed, shared and encrypted database that functions as an irreversible and } \\
\text { incorruptible public repository of information. }\end{array}$ & [6] \\
\hline 11 & $\begin{array}{l}\text { Blockchain is a technology that makes use of a distributed and decentralized architecture for record } \\
\text { transactions so that a record cannot be changed retroactively, making this record immutable. }\end{array}$ & [32] \\
\hline
\end{tabular}

Table 2. Summary of the main features of Blockchain.

\begin{tabular}{|c|c|c|}
\hline Features of Blockchain & Keywords & References \\
\hline $\begin{array}{l}\text { Two parties can make exchanges without the intermediation of } \\
\text { a third party. }\end{array}$ & Trust & \multirow{10}{*}{ [33] } \\
\hline Users control their transactions and the information transmitted. & Users' empowerment & \\
\hline Data made available through Blockchain is complete, dated, and accurate. & Quality & \\
\hline $\begin{array}{l}\text { Due to its distributed network, the Blockchain network has no central } \\
\text { point of failure. }\end{array}$ & Durability & \\
\hline Perform transactions as determined by established protocols. & Integrity & \\
\hline $\begin{array}{l}\text { Changes are publicly visible to all parties, and there is no possibility to } \\
\text { change or delete information. }\end{array}$ & Transparency and immutability & \\
\hline A single ledger. & Simplification of the ecosystem & \\
\hline $\begin{array}{l}\text { Transactions performed through the Blockchain can be completed in } \\
\text { minutes and are processed } 24 \mathrm{~h} \text { a day, } 7 \text { days a week. }\end{array}$ & Quickness & \\
\hline End of intermediaries. & Transaction costs, Decentralization & \\
\hline $\begin{array}{l}\text { Any document or asset can be expressed in code form or referenced by } \\
\text { a ledger entry. }\end{array}$ & Digital & \\
\hline $\begin{array}{l}\text { It is not necessary to have an intermediary that owns the entire data } \\
\qquad \text { logging repository. }\end{array}$ & Decentralization & \multirow{3}{*}{ [34] } \\
\hline End of intermediaries. & Transaction costs, Decentralization & \\
\hline $\begin{array}{l}\text { For any change in a block, all subsequent blocks are also changed, so } \\
\text { that, once registered, there is no possibility of subsequent changes. }\end{array}$ & Immutability & \\
\hline
\end{tabular}


Table 2. Cont.

\begin{tabular}{|c|c|c|}
\hline Features of Blockchain & Keywords & References \\
\hline $\begin{array}{l}\text { As a new calculation would require enormous computational } \\
\text { processing, the existence of a long chain of blocks makes the entire } \\
\text { history of the Blockchain immutable. }\end{array}$ & Immutability, Security & [20] \\
\hline $\begin{array}{l}\text { A Blockchain network is premised not to depend on a central authority, } \\
\text { with the nodes of the network being responsible for validating the } \\
\text { transactions carried out. }\end{array}$ & Decentralization & \multirow{3}{*}{ [32] } \\
\hline $\begin{array}{l}\text { If an operation is not completed, all previous operations are reversed } \\
\text { and subsequent ones are cancelled. }\end{array}$ & Integrity & \\
\hline $\begin{array}{l}\text { Ability to view any and all transactions on the Blockchain network, by } \\
\text { any node belonging to the network }\end{array}$ & Transparency & \\
\hline Trust is intrinsic, not extrinsic. & Integrity of the network & \multirow{7}{*}{ [1] } \\
\hline $\begin{array}{l}\text { Power distribution through a point-to-point network with no } \\
\text { point of control. }\end{array}$ & Distributed power & \\
\hline The system aligns the incentives of all participants. & Value as incentive & \\
\hline $\begin{array}{l}\text { Security measures are built into the network with no point of failure } \\
\text { and participants must use encryption. }\end{array}$ & Security & \\
\hline $\begin{array}{l}\text { By eliminating mistrust between people, there is no need to know their } \\
\text { true identities, thus ensuring users' anonymity. }\end{array}$ & Privacy, Anonymity & \\
\hline Property rights and individual freedoms are recognized and respected. & Reserved rights & \\
\hline The economy works when it works for everyone. & Inclusion & \\
\hline
\end{tabular}

To facilitate the understanding and subsequent analysis of the Blockchain construct, seven dimensions were consolidated from Table 2, according to the ideas of Oberländer et al. [35]. and Nickerson et al., [36] on the creation of a taxonomy to consolidate different perspectives ascribed to a construct. Table 3 presents these dimensions as well as the keywords associated with them.

Table 3. Main Dimensions of the Blockchain Construct.

\begin{tabular}{cc}
\hline Privacy & Users' empowerment; Reserved rights; Privacy; Anonymity \\
\hline Inclusion & Inclusion \\
\hline Integrity & Integrity; Integrity of the network \\
\hline Decentralization & Decentralized; Distributed power \\
\hline Security & Security; Trust; Data immutability; Quality; Durability \\
\hline Simplification & Simplification of the ecosystem; Transaction costs; Digital \\
\hline Value & Value as incentive \\
\hline
\end{tabular}

\subsubsection{Social Representation Theory}

The theme of collective representations, proposed by Émile Durkheim in 1886, was rescued by Serge Moscovici in 1950 and published in 1961, through his doctoral dissertation entitled "La Psychanalyse, son image et son public" [37]. Durkheim, through collective consciousness, eliminated or minimized individual differences, creating a "unity" based on the reflection of collective representations. These collective representations, as well as "social facts", have coercive power, are outside the individuals, and predate them [38]. That way, Moscovici drew on Durkheim's "collective" concept to create the concept of social representation [38]. Moscovici considers representation a form of socially elaborated and shared knowledge, according to the psychological and affective reality in which individuals are inserted [38]. 
According to Sêga [39], social representations seek to understand everyday reality. This is based on the knowledge developed by society and social groups, which determines their reactions and perceptions about the events and situations they are part of. In other words, social representation is the practical knowledge that justifies customs, contributing to the social construction of reality [39]. For Jodelet [40], it is important to understand the relationship between a person (or object) and the environment in which they are inserted, as it is in a group and not in isolation that the world is shared, and representations of reality are created.

Another definition of social representation, very much used due to its clarity and conciseness, is that of Jodelet as quoted by Mazzotti [41], p. 18: "a form of socially elaborated and shared knowledge, with the practical objective of contributing to the construction of a common reality for a social group".

The social representation theory (SRT), according to Arruda [42], establishes the existence of two different ways of understanding reality and communicating it, namely consensual and scientific. Both are indispensable for human life, with no hierarchy or separation between them, only with differentiated purposes. While the consensual form is mainly constituted by everyday life, the scientific form is constituted by its internal laws, rules, and hierarchies. For Arruda [42], social representations are more often developed in the consensual sphere. Besides, Vala [43] argues that social representations feed not only on scientific theories but also on major cultural axes, formalized ideologies, experiences, and everyday communications.

Based on those ideas, Moscovici began a rehabilitation of common sense and popular knowledge, going against the Enlightenment and Marxist ideals that believed that the overcoming of error and ignorance would only happen through the scientific universe [42]. In this sense, approaches were developed to implement SRT in a practical way, such as the Central Nucleus Theory developed by Abric [44] and presented below.

\subsubsection{Central Nucleus and Peripheral System}

The central nucleus theory was proposed by Jean-Claude Abric in 1976, as a complement to Moscovici's Social Representation Theory, being later complemented by other collaborators of Abric [41,45,46]

Abric's proposal establishes different levels of importance for the elements that make up a social representation [47]. The most important elements are organized in the so-called central nucleus, which gives meaning to the representation, and the less important ones comprise the peripheral system. For Abric, every social representation is organized around a central nucleus that, simultaneously, determines its meaning and its form of internal organization [47]. Indeed, the central nucleus is directly linked to historical, ideological, and sociological conditions, that is, to collective memories and norms that govern a social group. In it are the social thoughts that underlie the identity and continuity of the social group in question, which tend to be non-negotiable [41]. The categories that comprise the central nucleus are, therefore, more stable and resistant to change $[47,48]$. When undergoing some modification, the central nucleus of a social representation creates a new identity [41,48]. However, such modifications in it are rare and, generally, restricted to situations that lead the individual to radically revise their values and expectations [49]. Besides, the central nucleus has three essential functions [50]:

(a) Generator-associated with the creation or transformation of a social representation.

(b) Organizer-associated with the nature of the connections between the elements of a representation.

(c) Stabilizer-associated with elements that are more resistant to change.

In addition to the central nucleus, there is the peripheral system, which constitutes the operative part of the social representation, being less stable than the central nucleus. The peripheral system supports the heterogeneity of the group and its impasses without, however, affecting the central nucleus [41-50]. 
The characteristics of the central nucleus and the peripheral system are summarized in Table 4.

Table 4. Characteristics of the central nucleus and peripheral system of a social representation.

\begin{tabular}{cr}
\hline \multicolumn{1}{c}{ Central Nucleus } & Peripheral System \\
\hline Linked to collective memory and group history & Allows the integration of individual experiences and stories \\
\hline Consensual: defines the homogeneity of the group & Supports group heterogeneity \\
\hline Stable, coherent, and rigid & Flexible, supports contradiction \\
\hline Resists change & Transforms \\
\hline Little sensitive to immediate context & Sensitive to immediate context \\
\hline $\begin{array}{c}\text { Generates the meaning of the representation and determines } \\
\text { its organization }\end{array}$ & $\begin{array}{c}\text { Allows adaptation to concrete reality and content } \\
\text { differentiation-protects the central nucleus }\end{array}$ \\
\hline
\end{tabular}

According to Valle et al. [51], a social representation varies little due to debates of ideas or even new experiences since it does not originate from rational processes of reality analysis. Social representation is concretely linked to the individual, becoming a parameter to delineate the relationship of the subject who has it with the represented object.

Therefore, the main interest of this research is to identify the central nucleus of the social representation of Blockchain, according to Brazilian professionals without, however, neglecting the peripheral system of same, as it is presented in the next section.

\section{Methodological Procedures}

To achieve its objective, this work used the social representation theory with data collection performed via the words evocation technique and data analysis carried out through the four quadrants approach proposed by Jean-Claude Abric and operationalized by Pierre Vergès $[46,49,52,53]$.

Thus, an electronic questionnaire made available through an online platform was applied. The questionnaire was submitted to a previously defined population (individuals with prior knowledge of Blockchain), being composed of two parts: words evocation and ancillary questions to capture the profile of the respondents.

\subsection{Data Collection}

The selected sample involved professionals familiar with Blockchain, regardless of their academic background or area of professional activity. In fact, all respondents should be acquainted with the Blockchain concept due to the need to get a social representation from people who really know the subject. Indeed, the lack of basic knowledge on the subject, on the part of the interviewees, could weaken the reliability of the research $[47,54]$. Thus, a very important preliminary question was to ask the professionals contacted if they were familiar with the Blockchain concept. If the answer was negative, the data obtained from this respondent were not considered in the analysis performed.

To obtain the necessary information for this research, two steps were performed: literature review and empirical research. In the first stage, a bibliographical research was carried out in search of the Blockchain concept according to the academic literature. Subsequently, empirical research was carried out and subdivided into two phases:

- Application of the word evocation technique.

- Application of a complementary questionnaire to identify the profile of the interviewees.

The electronic form was made available from 2 June 2020 to 28 August 2020. A link was sent to WhatsApp groups about Blockchain and LinkedIn's "advertising" tool. 
In the first part of the questionnaire, the respondent was asked to cite the five words or expressions that first came to mind when faced with the expression Blockchain [54]. In the second part of the questionnaire, questions were formulated in order to obtain the profile of the respondents.

\subsection{Data Analysis}

To analyze the evoked expressions, the Vergès' four quadrants technique was adopted. According to it, the words or expressions evoked are placed in four quadrants, enabling the depiction and analysis of the social representation in question [46-52]. The four quadrants technique consists of crossing the frequencies of evocation of words, of a quantitative nature, with the order of evocation, of a qualitative nature [44]. Table 5 shows each of the four quadrants of the Vergès' framework.

Table 5. Summary of Vergès' quadrants.

Central Nucleus
Evocations with evocation frequency greater than (or equal to)
the average frequency of evocation (AFE) and with an evocation
order lower than the average order of evocation (AOE).

\section{Contrast Zone}

Evocations with evocation frequency lower than the average frequency of evocation (AFE) and with an evocation order lower than the average order of evocation (AOE). Close link with the Central Nucleus

\section{First Periphery}

Evocations with evocation frequency greater than (or equal to) the average frequency of evocation (AFE) and with an evocation order greater than (or equal to) the average order of evocation (AOE). Close link with the Central Nucleus

\section{Peripheral System}

Evocations with evocation frequency lower than the average frequency of evocation (AFE) and with an evocation order greater than (or equal to) the average order of evocation (AOE). Weak link with the Central Nucleus

Source: Adapted from [55], p. 48.

Upper left quadrant: categories capable of generating, in a stable and organized way, the meaning of the social representation (Central Nucleus).

Upper right quadrant: categories frequently cited by respondents but not very important to them (First Periphery).

Lower left quadrant: categories considered important for a small group of respondents (Contrast Zone).

Lower right quadrant: categories of little relevance to the social representation and contrasting with its central nucleus (Peripheral System).

For the elaboration of the Vergès' quadrant, it is necessary that two parameters are calculated: the average frequency of evocation (AFE) and the mean value of the average order of evocation (AOE) of the words [47]. These values are reference points for correctly disposing the evoked words within each quadrant, crossing, for each word, the frequency of evocation, of a quantitative nature, with the average order of evocation, of a qualitative nature $[47,55,56]$.

The average frequency of evocation (AFE) refers to the average number of times the words were evoked, and its calculation is performed by dividing the total sum of words evoked in each category by the number of categories found. In addition, the average order of evocation (AOE) of a category corresponds to the average order in which the words that make up that category were evoked. The average value of the AOE is obtained by dividing the sum of all AOEs by the number of existing categories [47,54,57].

After doing that, it is possible to place each of the evoked categories in one of the four Vergès' quadrants (Figure 1).

The categories positioned in the first periphery or in the contrast zone have an inconclusive interpretation, as although they have a close relationship with the central nucleus, they do not belong to it [58]. 
AVERAGE ORDER OF EVOCATION (AOE)

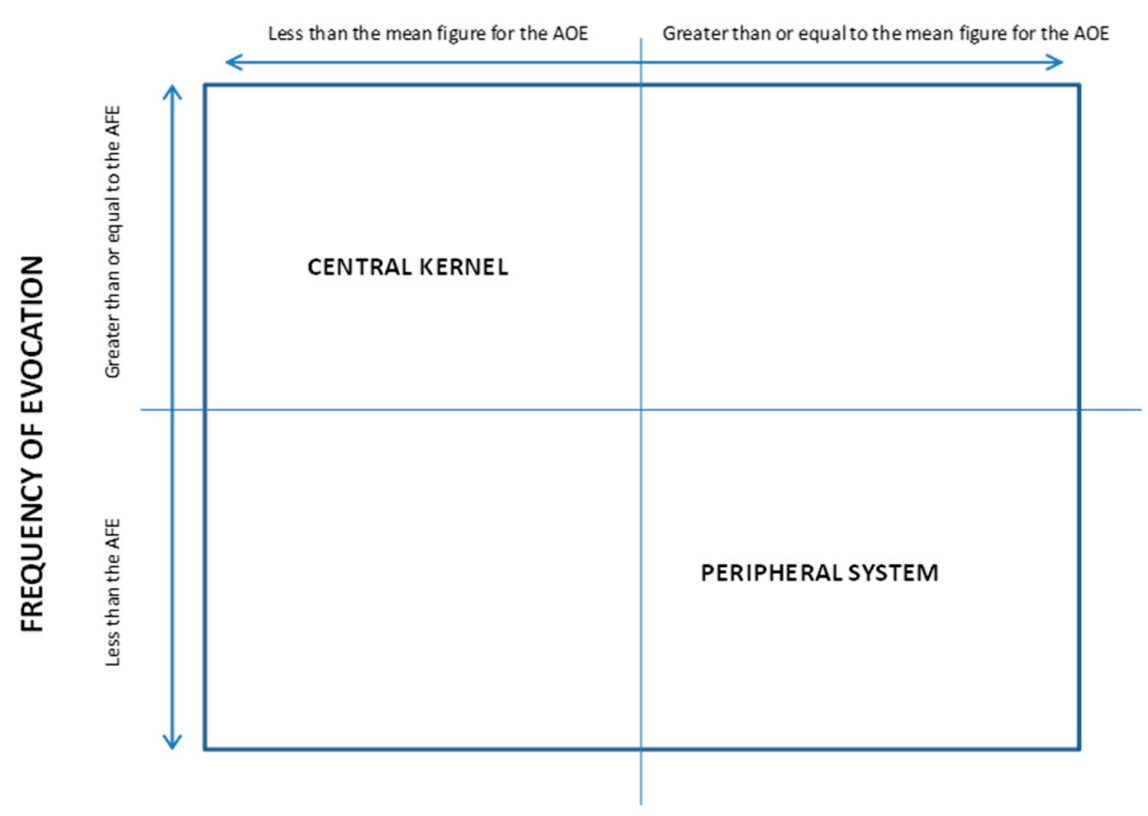

Figure 1. The Four Quadrants of Vergès. Source: Joia and Marchisotti [59], p. 901.

\section{Results}

\subsection{Sample}

The questionnaire was sent to around 20,500 users of WhatsApp groups about Blockchain and LinkedIn's "advertising" tool as the target of this research was to capture the perception of professionals who had familiarity with the Blockchain concept, as already said. From this universe, a total of 324 answered questionnaires were obtained, of which $135(42 \%)$ were considered valid.

According to Wachelke et al. [60], a number of respondents between 100 and 200 is adequate for composing a social representation. Thus, the sample size obtained can be considered satisfactory.

Table 6 presents the characteristics of the sample.

Table 6. Characteristics of the sample.

\begin{tabular}{cr}
\hline Item & Characteristics of the Sample \\
\hline 1 & The sample with 135 respondents met the minimum satisfactory conditions for the success of this research. \\
\hline 2 & All respondents had heard of Blockchain. \\
\hline 3 & Average age of 39.7 years and average professional experience of 14 years. \\
\hline 4 & Marge concentration of respondents in Brazil's southeast region, totaling $84 \%$ of the sample. \\
\hline 6 & The educational background of respondents focused on: Administration and IT, representing $62 \%$ of the sample. \\
\hline 7 & $57 \%$ of respondents said the company they worked for was involved with Blockchain. \\
\hline 9 & Only $15.2 \%$ of respondents had no direct involvement with Blockchain. \\
\hline 10 & The positions of the interviewees were heterogeneous, distributed between managers and non-managers. \\
\hline
\end{tabular}

\subsection{Central Nucleus and Peripheral System}

Of the 135 respondents considered valid for this research, all responded to the evocation test, totaling 675 evoked words. However, 49 words (7.26\%) were excluded from 
the analysis because they were evoked only once or because they were incomprehensible and/or out of the research context. The evoked words must be grouped according to their semantic groups and discarded if they have been evoked only once [54]. After collecting the evoked words, it is necessary to organize and group them according to their respective semantic categories [57]. Table 7 shows the overall numbers of the words evocation test.

Table 7. General data of the word evocation test.

\begin{tabular}{cc}
\hline \multicolumn{2}{c}{ General Data } \\
\hline Number of individuals who answered the questionnaire & 135 \\
\hline Total words or phrases evoked & 675 \\
\hline Total words or phrases discarded & 49 \\
\hline Total words or phrases categorized & 626 \\
\hline Total categories analyzed & 66 \\
\hline
\end{tabular}

After categorizing the evoked words, it is necessary to identify which groups are relevant to constitute the Vergès' quadrants. Therefore, three basic steps must be performed so that the formulation of the quadrants is possible:

1. Definition of the minimum frequency of words evocation.

2. Calculation of the average frequency of evocation (AFE).

3. Calculation of the mean value of the average order of evocation (AOE).

To define the minimum frequency of evocation of words, the approach recommended by Vergès was adopted, which suggests a percentage around $50 \%$ of the accumulation of evocations as the minimum frequency of evocation [47]. Thus, Table 8 shows that the accumulation of evoked words with frequencies ranging between 20 and 91 represents $50.07 \%$ of the total of 675 evoked words. This totals eight distinct categories evoked 338 times (see Table 8).

Table 8. Distribution of the frequencies of evocation.

\begin{tabular}{|c|c|c|c|c|c|}
\hline \multirow{2}{*}{$\begin{array}{c}\text { Frequency of Evocation } \\
1\end{array}$} & \multirow{2}{*}{$\begin{array}{c}\text { Number of Categories } \\
49\end{array}$} & \multicolumn{2}{|c|}{ Evocation Accumulation } & \multicolumn{2}{|c|}{ Inverse Accumulation } \\
\hline & & 49 & $7.26 \%$ & 675 & $100.00 \%$ \\
\hline 2 & 21 & 91 & $13.48 \%$ & 626 & $92.74 \%$ \\
\hline 3 & 8 & 115 & $17.04 \%$ & 584 & $86.52 \%$ \\
\hline 4 & 8 & 147 & $21.78 \%$ & 560 & $82.96 \%$ \\
\hline 5 & 4 & 167 & $24.74 \%$ & 528 & $78.22 \%$ \\
\hline 6 & 3 & 185 & $27.41 \%$ & 508 & $75.26 \%$ \\
\hline 7 & 4 & 213 & $31.56 \%$ & 490 & $72.59 \%$ \\
\hline 9 & 2 & 231 & $34.22 \%$ & 462 & $68.44 \%$ \\
\hline 10 & 1 & 241 & $35.70 \%$ & 444 & $65.78 \%$ \\
\hline 11 & 1 & 252 & $37.33 \%$ & 434 & $64.30 \%$ \\
\hline 12 & 2 & 276 & $40.89 \%$ & 423 & $62.67 \%$ \\
\hline 13 & 1 & 289 & $42.81 \%$ & 399 & $59.11 \%$ \\
\hline 15 & 1 & 304 & $45.04 \%$ & 386 & $57.19 \%$ \\
\hline 16 & 1 & 320 & $47.41 \%$ & 371 & $54.96 \%$ \\
\hline 17 & 1 & 337 & $49.93 \%$ & 355 & $52.59 \%$ \\
\hline 20 & 1 & 357 & $52.89 \%$ & 338 & $50.07 \%$ \\
\hline 24 & 1 & 381 & $56.44 \%$ & 318 & $47.11 \%$ \\
\hline
\end{tabular}


Table 8. Cont.

\begin{tabular}{|c|c|c|c|c|c|}
\hline \multirow{2}{*}{$\begin{array}{c}\text { Frequency of Evocation } \\
27\end{array}$} & \multirow{2}{*}{$\begin{array}{c}\text { Number of Categories } \\
1\end{array}$} & \multicolumn{2}{|c|}{ Evocation Accumulation } & \multicolumn{2}{|c|}{ Inverse Accumulation } \\
\hline & & 408 & $60.44 \%$ & 294 & $43.56 \%$ \\
\hline 39 & 1 & 447 & $66.22 \%$ & 267 & $39.56 \%$ \\
\hline 40 & 1 & 487 & $72.15 \%$ & 228 & $33.78 \%$ \\
\hline 45 & 1 & 532 & $78.81 \%$ & 188 & $27.85 \%$ \\
\hline 52 & 1 & 584 & $86.52 \%$ & 143 & $21.19 \%$ \\
\hline 91 & 1 & 675 & $100.00 \%$ & 91 & $13.48 \%$ \\
\hline
\end{tabular}

Based on Table 8, the value of $50.07 \%$ (Column Inverse Accumulation) was adopted, close to $50 \%$. Thus, the minimum frequency of word evocation is 20 . With the adoption of the cutoff point in 20 evocations, the Verges' quadrant is now represented only by categories with evocation equal to or greater than 20 occurrences, i.e., only eight $(6.9 \%)$ of the 116 categories originally constituted met the minimum frequency premise for the construction of the Blockchain's social representation.

Table 9 presents the categories found as well as the respective number of evocations and their position within the total evocation universe.

Table 9. Categories and counting of evocations.

\begin{tabular}{ccc}
\hline Category & Evocations & $\%$ \\
\hline Security & 91 & $13.48 \%$ \\
\hline Bitcoin & 52 & $7.70 \%$ \\
\hline Cryptocurrency & 45 & $6.67 \%$ \\
\hline Technology & 40 & $5.93 \%$ \\
\hline Decentralization & 39 & $5.78 \%$ \\
\hline Innovation & 27 & $4.00 \%$ \\
\hline Data & 24 & $3.56 \%$ \\
\hline Network & 20 & $2.96 \%$ \\
\hline
\end{tabular}

Continuing the assembly of the Vergès' quadrant, it is necessary to meet the second basic premise-calculate the average frequency of those eight categories, obtaining the value of 40.00 [61].

Finally, to meet the last premise, it is necessary to calculate the average value of the AOE. To perform this calculation, the following formula is used:

$$
\mathrm{OME}=\frac{(\mathrm{f} 1 \text { st. place } \times 1)+(\mathrm{f} 2 \text { nd. place } \times 2)+(\mathrm{f} 3 \text { rd. place } \times 3)+(\mathrm{f} 4 \text { th. place } \times 4)+(\mathrm{f} 5 \text { th. place } \times 5)}{\sum \mathrm{f}}
$$

The AOE of a semantic category is obtained by dividing the sum of the frequencies of the component words, weighted by the hierarchy given by the respondent, by the total value of evocations in the category $\left(\sum \mathrm{f}\right)$. Thus, $\mathrm{f} 1$ corresponds to the number of times a word in the category was evoked in the first position, $\mathrm{f} 2$ corresponds to the number of times a word in the category was evoked in the second position, successively up to f5, with the number of times a word in the category was evoked in the fifth position. Finally, this sum is divided by the total sum of times the words in the category were evoked $(\mathrm{f} 1+\mathrm{f} 2+\mathrm{f} 3+\mathrm{f} 4+\mathrm{f} 5)[47,62]$. Thus, the third and last premise for the elaboration of the central core and peripheral system is met. Table 10 presents the calculated values. 
Table 10. The calculated values. Values for the composition of the Vergès quadrant.

\begin{tabular}{cc}
\hline Premises & Values \\
\hline Minimum Frequency of Evocation & 20 \\
\hline Average Frequency of Evocation (AFE) & 40 \\
\hline Average AOE & 2.77 \\
\hline
\end{tabular}

With the values above, the categories found were placed in the Quadrant of Vergès, as shown in Figure 2.

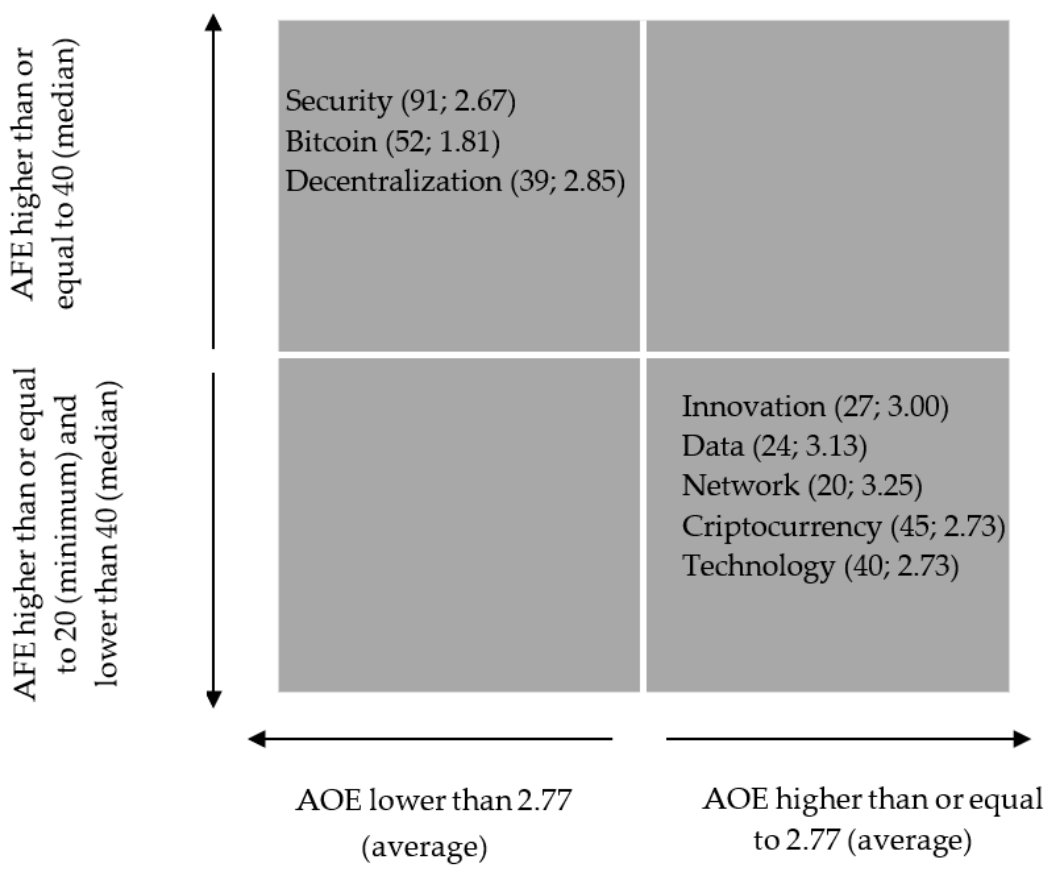

Figure 2. Vergés' quadrant for Blockchain.

\section{Discussion}

Three categories were placed at the central nucleus of the Blockchain's social representation-security, bitcoin, and decentralization, which are discussed below.

The most mentioned category was Security. Security refers to the combination of integrity, availability, and confidentiality, being a basic principle of any information system. Blockchain meets the three conditions listed. Integrity is guaranteed through cryptographic mechanisms and availability through network decentralization, which allows connection to multiple users and storage of copies in blocks on the network. Finally, confidentiality is guaranteed by pseudo-user anonymity mechanisms—cryptographic summaries of public keys [63].

The Bitcoin category has the second highest frequency of evocation, but it is the term with the lowest AOE. That is, when evoked, it is the category that first comes to the respondents' minds. Such importance is easily justified since Blockchain came along with bitcoin. In other words, it would not be believable to explain Blockchain without relating it to virtual cryptocurrencies, more precisely with bitcoin, since both are deeply related [64].

Regarding the Decentralization category, Roman [65] states that Blockchain is a technology based on the decentralization of information control. When the control of information is centralized in a single individual, the integrity of the system is totally dependent on this person. On the other hand, when there is decentralization, integrity depends on all members of the ecosystem, not being linked to the unilateral will of one single person (Romano, [65]. In this way, decentralization strengthens data integrity, which is one of the dimensions of security. 
On the other hand, the following categories comprise the peripheral system: Innovation, Technology, Cryptocurrency, Data, and Network. The location of these terms in the peripheral system means that they are of lesser importance to respondents, being flexible categories that can adapt to circumstances [52].

In relation to the Innovation category, its location in the peripheral system indicates that the Brazilian professionals have doubts whether the Blockchain technology can be effectively perceived as an innovation. Indeed, for Henderson and Clark (1990) there are four types of innovation: incremental, modular, architectural, and radical; radical and incremental innovations being considered as opposites [66]. Blockchain could be understood as a radical innovation, changing the context to which it belongs by providing a new form of relationship between the links in the chain. However, Dannen [67] claims that Blockchain is a combination of three distinct technologies that have been available for some time: peer-to-peer connection, encryption, and cryptographic hashing. Thus, Blockchain could be classified as an architectural innovation, whose concept is based on the rearrangement of interactions that already exist between the components of a product, giving rise to new relationships in the system [66].

In relation to the Technology, Network, and Data categories, it can be observed that all are intrinsically related to the technological characteristics of Blockchain. That is, they say little about the definition of Blockchain outside a technological context. It is normal for respondents, spontaneously and during an evocation of words, to associate (or confuse) a concept with its intrinsic characteristics $[49,59]$. Thus, these dimensions do little to model the Blockchain definition.

The Cryptocurrency category, on the other hand, has a strong connection with the term bitcoin - the most widespread cryptocurrency in the world. Thus, once again, the overlap between the concept of Blockchain and the various types of cryptocurrencies existing today can be seen [68].

Based on the analysis of the terms that constitute the central nucleus of the Blockchain's social representation, one can assess its correspondence with the scientific literature on the subject. In this research, seven dimensions were listed as the main characteristics of the Blockchain technology according to the scientific literature (Table 3).

Privacy

Inclusion

Integrity

Decentralization

Security

Simplification

Value

Based on the results found, a dissonance between the perception of Brazilian professionals on the concept of Blockchain and the scientific literature on the subject can be noticed. Figure 3 presents, in a synthesized way, this result.

As can be seen, of the seven dimensions associated with the concept of Blockchain according to the academic literature, only two (Security and Decentralization) were placed in the central nucleus of the social representation of the Blockchain according to Brazilian professionals. Furthermore, in Brazil there is a great overlap between the Blockchain technology and the bitcoin cryptocurrency (also located in the central nucleus).

Thus, Figure 3 points to a still immature perception of Brazilian professionals about the real potential of the Blockchain technology. For example, it appears that privacy, data integrity, and simplification of operational processes were not perceived as associated with Blockchain by Brazilian professionals. Furthermore, the Blockchain's potential to enable improvements in digital, social, educational, political and, above all, financial inclusion [69-72] in a nation where such exclusions are significant, was not even cited by respondents, despite being featured in the academic literature on Blockchain.

Likewise, professionals did not realize how Blockchain can add value to products and services. Thus, this research reveals a more operational than strategic view on the part of 
Brazilian professionals about Blockchain, disregarding the potential for the competitiveness of companies [73].

\begin{tabular}{|l|l|}
\hline ACADEMIC LITERATURE & CENTRAL NUCLEUS \\
& - Security \\
- Privacy & - Bitcoin \\
- Inclusion & - Decentralization \\
- Integrity & \\
\hline - Decentralization & PERIPHERAL SYSTEM \\
- Security & - Innovation \\
- Simplification & - Cryptocurrencies \\
- Value & - Technology \\
& - Data \\
& - Network \\
\hline
\end{tabular}

Figure 3. Blockchain social representation vs. scientific literature.

Furthermore, the peripheral system points to a very technocentric view of Blockchain, mainly associated with data and computational network. As the peripheral system categories are negotiable, it is expected that, over time, this technicist view will be partially replaced by a strategic approach, from which the Blockchain's greatest impact on business will certainly come [74-76].

Finally, it appears that Brazilian professionals are not convinced that Blockchain is really an innovation. This fact is corroborated by the scientific literature, as explained above. Blockchain can be considered, at most, an architectural innovation, as it only inventively combines technologies that were already available on the market [77].

\section{Conclusions}

The first conclusion arising from this work is the technical and operational vision that Brazilian professionals have in relation to Blockchain. There is also a great overlap between the comprehensive concept of Blockchain and one of its main (if not the most important) applications, bitcoin, and, in a secondary way, other cryptocurrencies. Thus, Brazilian professionals disregard the strategic potential of Blockchain in the digital transformation of public [78] and private [79] organizations.

Likewise, Blockchain's potential to enable inclusion in a developing country like Brazil, with great socio-economic inequalities, was totally disregarded by respondents.

In addition, innovative Blockchain applications such as those for document authentication [80], land registration [81], smart contracts [82], electronic voting [83], smart cities [84], and Internet of Things-based supply chain management, among others, were not even mentioned by the respondents [85].

Furthermore, Brazilian professionals did not realize the need and relevance of a specific governance for Blockchain [86]. In fact, so far, this issue has also been overlooked by academia, which shows that this is a point that both theory and practice need to advance [14-16,87-91].

\subsection{Academic and Managerial Implications}

From an academic point of view, this paper discussed the cognitive dissonance between the perception of Brazilian professionals and the scientific literature on the definition 
of Blockchain. Thus, it was found that the Blockchain construct, as understood by academia, is not perceived in the same way by Brazilian professionals. This issue must be taken into account by academia, since it is clear that theory and practice related to Blockchain have not gone hand in hand in an emerging market like Brazil.

In addition, the work evidenced the relevance of SRT for defining newly created constructs, whose understanding still needs to be solidified. This fact has been very common in the IT arena, with the emergence, day after day, of concepts such as IoT, machine learning, 5G, and RPA, among others. According to Priem and Butler [89], constructs must be robust enough for observers to have no hesitation in recognizing and investigating them. Furthermore, constructs are the foundation of any theory [90,91].

Moreover, the partial misalignment between theory and practice on Blockchain clearly shows that most of the current academic literature on Blockchain encompass the context of developed countries rather than the emerging countries like Brazil. Therefore, a body of knowledge on Blockchain related to the social, political, economic, and technological environment of developing countries must be developed to prevent organizations in emerging markets from misleadingly imitating those in developed countries with regard to the development and implementation of Blockchain applications.

From a managerial point of view, as the research evidenced a gap between the professionals' perception and the scientific literature on Blockchain, problems in the large-scale development and use of Blockchain in Brazil and other developing countries can be expected, since the lack of knowledge or misconceptions about Blockchain can reverberate negatively, bringing damages in the analysis of usability and disruptive potential of it. In this sense, capacity-building initiatives can be developed by organizations, aiming to give their professionals an understanding of the strategic potential of Blockchain, since they demonstrated a technocentric vision, disregarding its transformational potential in both the public and private arenas.

Furthermore, as already pointed out, the results showed that Brazilian professionals did not realize the Blockchain's inclusiveness potential in an emerging market like Brazil, a fact also supported by Verschoore et al. [12]. In that way, governments and civil society could develop awareness-raising initiatives on how Blockchain can help emerging markets move closer to the UN Sustainable Development Goals. Finally, Brazilian professionals did not realize the need and relevance of a specific legal governance for Blockchain, a topic also little researched by academia. This fact reveals the need for a research agenda on this topic.

\subsection{Research Limitations}

This research has some limitations, described below, which should be considered when applying the results of this work.

Most of the respondents in this research are located in the southeast region of Brazil. This result is justifiable, given the selection of professionals through WhatsApp groups with participants concentrated in this most developed region in Brazil. As such, the result could have been different with the regional expansion of the sample. Furthermore, although the number of respondents was satisfactory, increasing the sample would be important to obtain greater representation and increase the reliability of the research.

Another limitation refers to the grouping of the 675 words evoked into 116 different categories. This process, even following the rules suggested by the scientific literature, has a certain degree of subjectivity and may have been influenced by a possible bias on the part of the researchers.

All in all, Information Technology has brought new constructs associated with emerging technologies. Thus, it is not difficult to see that this area of knowledge will be continually facing the challenge of defining, in a consistent and monosemic way, new technological concepts [59]. It is hoped, therefore, that this work has contributed to a better understanding of the Blockchain construct. 
Author Contributions: Conceptualization, L.A.J.; methodology, L.A.J.; software, J.A.P.V.; validation, L.A.J. and J.A.P.V.; formal analysis, J.A.P.V.; investigation, J.A.P.V.; resources, L.A.J. and J.A.P.V.; data curation, J.A.P.V.; writing—original draft preparation, J.A.P.V.; writing—review and editing, L.A.J.; visualization, J.A.P.V.; supervision, L.A.J.; project administration, L.A.J.; funding acquisition, L.A.J. All authors have read and agreed to the published version of the manuscript.

Funding: This research was funded by Brazilian National Council for Scientific and Technological Development (CNPq) grant number PQ 306517/2018-3, and The APC was funded by Brazilian School of Public and Business Administration at Getulio Vargas Foundation grant number 00505100300360.

Institutional Review Board Statement: Ethical review and approval were waived for this study as the participants answered the survey anonymously and cannot be identified.

Informed Consent Statement: Not applicable.

Data Availability Statement: The dataset used in the article can be found at https:/ / bibliotecadigital. fgv.br/dspace/handle/10438/28078, in Portuguese.

Conflicts of Interest: The authors declare no conflict of interest.

\section{References}

1. Tapscott, D.; Tapscott, A. Blockchain Revolution; Portfolio Company: New York, NY, USA, 2016.

2. Konstantinidis, I.; Siaminos, G.; Timplalexis, C.; Zervas, P.; Peristeras, V.; Decker, S. Blockchain for business applications: A systematic literature review. In International Conference on Business Information Systems; Springer: Cham, Switzerland, 2018; pp. 384-399.

3. Yli-Huumo, J.; Ko, D.; Choi, S.; Park, S.; Smolander, K. Where is current research on blockchain technology?-A systematic review. PLoS ONE 2016, 11, e0163477. [CrossRef]

4. Yermack, D. Corporate governance and blockchains. Rev. Financ. 2017, 21, 7-31. [CrossRef]

5. Ulrich, F. Bitcoin: A Moeda na Era Digital; Instituto Ludwig von Mises: São Paulo, Brasil, 2014.

6. Wright, A.; De Filippi, P. Decentralized Blockchain Technology and the Rise of Lex Cryptographia. 2015. Available online: https://ssrn.com/abstract=2580664 (accessed on 16 December 2021).

7. Fosso Wamba, S.; Kala Kamdjoug, J.R.; Epie Bawack, R.; Keogh, J.G. Bitcoin, Blockchain and Fintech: A systematic review and case studies in the supply chain. Prod. Plan. Control. 2020, 31, 115-142. [CrossRef]

8. Frizzo-Barker, J.; Chow-White, P.A.; Adams, P.R.; Mentanko, J.; Ha, D.; Green, S. Blockchain as a disruptive technology for business: A systematic review. Int. J. Inf. Manag. 2020, 51, 102029. [CrossRef]

9. De Kruijff, J.; Weigand, H. Understanding the blockchain using enterprise ontology. In International Conference on Advanced Information Systems Engineering; Springer: Cham, Switzerland, 2017; pp. $29-43$.

10. Kvint, V. The Global Emerging Market: Strategic Management and Economics; Routledge: New York, NY, USA; London, UK, 2009.

11. Martins, A.M.; Guimaraes, C.; dos Santos, M.N. Innovation and impact from a Brazilian perspective. In Sustainabl Innovation and Impact; Routledge: London, UK, 2018; pp. 165-170.

12. Verschoore, J.R.; Diniz, E.H.; Colomo-Palacios, R. Blockchain, Cryptocurrencies, and Distributed Organizations. BA Braz. Adm. Rev. 2021, 18, e210109. [CrossRef]

13. Petroni, B.C.A.; Pfitzner, M.S. A Framework of Blockchain Technology for Public Management in Brazil. In Blockchain and the Public Sector; Springer: Cham, Switzerland, 2021; pp. 151-174.

14. Tandon, A.; Kaur, P.; Mäntymäki, M.; Dhir, A. Blockchain applications in management: A bibliometric analysis and literature review. Technol. Forecast. Soc. Chang. 2021, 166, 120649. [CrossRef]

15. Adams, R.; Kewell, B.; Parry, G. Blockchain for good? Digital ledger technology and sustainable development goals. In Handbook of Sustainability and Social Science Research; Springer: Cham, Switzerland, 2018; pp. 127-140.

16. Medaglia, R.; Damsgaard, J. Blockchain and the United Nations Sustainable Development Goals: Towards an Agenda for IS Research. In Proceedings of the Pacific Conference on Information Systems (PACIS), Dubai, United Arab Emirates, 20-24 June 2020; p. 36.

17. Khanfar, A.A.; Iranmanesh, M.; Ghobakhloo, M.; Senali, M.G.; Fathi, M. Applications of blockchain technology in sustainable manufacturing and supply chain management: A systematic review. Sustainability 2021, 13, 7870. [CrossRef]

18. Nakamoto, S. Bitcoin: A Peer-to-Peer Electronic Cash System. 2008, p. 9. Available online: https://bitcoin.org/bitcoin.pdf (accessed on 22 October 2017).

19. Diniz, E.H. Emerge uma nova tecnologia disruptiva. GV Exec. 2017, 16, 46-50. [CrossRef]

20. Antonopoulos, A.M. Mastering Bitcoin: Programming the Open Blockchain; O’Reilly Media, Inc.: Sebastopol, CA, USA, 2017.

21. Hughes, A.; Park, A.; Kietzmann, J.; Archer-Brown, C. Beyond Bitcoin: What Blockchain and distributed ledger technologies mean for firms. Bus. Horiz. 2019, 62, 273-281. [CrossRef]

22. Underwood, S. Blockchain beyond bitcoin. Commun. ACM 2016, 59, 15-17. [CrossRef] 
23. Lakomski-Laguerre, O.; Desmedt, L. L'alternative monétaire Bitcoin: Une perspective institutionnaliste. Rev. De La Régulation Capital. Inst. Pouvoirs 2015, 18. Available online: https://ideas.repec.org/a/rvr/journl/201511489.html (accessed on 16 December 2021).

24. Blundell-Wignall, A. The Bitcoin Question: Currency versus Trust-Less Transfer Technology; OECD iLibrary: Paris, France, 2014.

25. Ferreira, J.E.; Pinto, F.G.C.; dos Santos, S.C. Estudo de mapeamento sistemático sobre as tendências e desafios do Blockchain. Gestão. Org. 2017, 15, 108-117. [CrossRef]

26. Aliaga, Y.E.M.; Henriques, M.A.A. Uma comparação de mecanismos de consenso em blockchains. In Proceedings of the Encontro dos Alunos e Docentes do Departamento de Engenharia de Computação e Automação Industrial, Campinas, Brazil, 26-27 October 2017; Volume 10.

27. Weernink, M.O.; van den Engh, W.; Fransisconi, M.; Thorborg, F. The Blockchain Potential for Port Logistics; White PaperBlockhain, 2017. Available online: https:/ / smartport.nl/wp-content/uploads/2017/10/White-Paper-Blockchain.pdf (accessed on 16 December 2021).

28. Salem, A. IBM Blockchain Research Lab, Blockchain: Beyond Finance. 2017. Available online: http://ceweb,br/webbr2017/ apresentacoes/1Andre\%CC\%81\%20Salem-Blockchain_VF,pdf (accessed on 16 December 2021).

29. Gupta, M. Blockchain for Dummies; John Wiley \& Sons: Hoboken, NJ, USA, 2017.

30. Kypriotaki, K.; Zamani, E.; Giaglis, G. From bitcoin to decentralized autonomous corporations-extending the application scope of decentralized peer-to-peer networks and blockchains. In Proceedings of the International Conference on Enterprise Information Systems, Barcelona, Spain, 27-30 April 2015.

31. Morabito, V. Business Innovation through Blockchain; Springer International Publishing: Cham, Switzerland, 2017.

32. Alves, J.; Pinto, A. On the use of the blockchain technology in electronic voting systems. In International Symposium on Ambient Intelligence; Springer: Cham, Switzerland, 2018; pp. 323-330.

33. Arruda, G.O. A Tecnologia a Serviço da Democracia: O Processo Eleitoral na Era da Informação. Rev. Advocacia Pública Fed. 2017, 1,139-149.

34. Carvalho, C.E.; Pires, D.A.; Artioli, M.; Contento, G. Bitcoin, Criptomoedas, Blockchain: Desafios Analíticos, Reação dos Bancos, Implicações Regulatórias1; Anais Fórum Liberdade Econômica: São Paulo, Brasil, 2017.

35. Oberländer, A.M.; Lösser, B.; Rau, D. Taxonomy Research in Information Systems: A Systematic Assessment. In Proceedings of the 27th European Conference on Information Systems (ECIS), Stockholm, Sweden; Uppsala, Sweden, 8-14 June 2019.

36. Nickerson, R.C.; Varshney, U.; Muntermann, J. A method for taxonomy development and its application in information systems. Eur. J. Inf. Syst. 2013, 22, 336-359. [CrossRef]

37. Moscovici, S. La Psychanalyse, Son Image et Son Public; Presses Universitaires de France: Paris, France, 2005.

38. Franco, M.L.P. Representações sociais, ideologia e desenvolvimento da consciência. Cad. Pesqui. 2004, 34, 169-186. [CrossRef]

39. Sêga, R.A. O conceito de representação social nas obras de Denise Jodelet e Serge Moscovici. Anos 90 2000, 8, 128-133. [CrossRef]

40. Jodelet, D. Representações sociais: Um domínio em expansão. In As Representações Sociais; Eduerj: Rio de Janeiro, Brazil, 2001; Volume 17, pp. 17-44.

41. Mazzotti, A.J.A. A abordagem estrutural das representações sociais, Psicologia da Educação, Programa de Estudos Pós-Graduados em Educação: Psicologia da Educação. 2002, Volume 14-15. Available online: https://revistas.pucsp.br/index.php/psicoeduca/ article/view/31913 (accessed on 16 December 2021).

42. Arruda, A. Teoria das representações sociais e teorias de gênero. Cad. De Pesqui. 2002, 127-147. [CrossRef]

43. Vala, J. As representações sociais no quadro dos paradigmas e metáforas da psicologia social. Análise Soc. 1993, $28,887-919$.

44. Abric, J.C. La Recherche du Noyau Central et de la Zone Muette des Représentations Sociales; Méthodes D'étude des Représentations Sociales: Toulouse, France, 2003; pp. 59-80.

45. Abric, J.C. Specific processes of social representations. Pap. Soc. Represent. 1996, 5, 77-80.

46. Vergès, P. EVOC_Ensemble de Programmes Permettant lAnalyse des Évocations: Manuel Version 15 Octobre 2003 [Set of Programs for Analysis of Evocations: Manual Version October 15, 2003]; Laboratoire Méditerranéen de Sociologie (LAMES): Aix-en-Provence, France, 2003.

47. Sá, C.P.D. Núcleo central das representações sociais. In Núcleo Central das Representações Sociais; EDUERJ: Rio de Janeiro, Brazil, 2002; p. 189.

48. Madeira, M. Representações sociais e educação: Importância teórico-metodológica de uma relação. In Representações Sociais: Teoria e Prática; UFPB: João Pessoa, Brazil, 2001; pp. 123-144.

49. Vergara, S.C.; Ferreira, V.C.P. Teoria das representações sociais: Uma opção para pesquisas em administração. Rev. Angrad 2007, 8, 225-241.

50. Abric:, J.C. Les représentations sociales: Aspects théoriques. Prat. Soc. Représentations 1994, 2, 11-37.

51. Valle, J.A.D.S.; Ferreira, V.C.P.; Joia, L.A. A representação social do escritório de gerenciamento de projetos na percepçãode profissionais da área. Gest. Prod. 2014, 21, 185-198. [CrossRef]

52. Abric, J.C. A abordagem estrutural das representações sociais. Estud. Interdiscip. Represent. Soc. 1998, 2, $27-38$.

53. Flament, C. L'analyse de similitude: Une technique pour les recherches sur les représentations sociales. In Cahiers de Psychlogie Cognitive/Current Psychology of Cognition; Laboratoire Méditerranéen de Sociologie (LAMES): Aix-em-Provence, France, 1981.

54. Joia, L.A. A Teoria da Representação Social e a Definição de Constructos Na Área de Administração da Informação; VI EnADI: Curitiba, Brazil, 2017. 
55. Marchisotti, G.G. A Representação Social do Cloud Computing na Visão dos Profissionais de TI Brasileiros. Master's Thesis, EBAPE/FGV, Rio de Janeiro, Brazil, 2014. Available online: https://bibliotecadigital.fgv.br/dspace/handle/10438/12824?show= full (accessed on 16 December 2021).

56. Correia, J.C.P. A Representação Social Do CIO No BRASIL na Percepção dos Profissionais de Tecnologia da Informação. Master's Thesis, EBAPE/FGV, Rio de Janeiro, Brazil, 2013.

57. Vergara, S.C. Métodos de Pesquisa em Administração; Atlas: São Paulo, Brazil, 2005.

58. Tura, L.F.R. Os Jovens e a Prevenção da AIDS no Rio de Janeiro. Doctoral Dissertation, Universidade Federal, Rio de Janeiro, Brazil, 1997.

59. Joia, L.A.; Marchisotti, G. It is so! (if you think so!)—IT professionals' social representation of cloud computing. Internet Res. 2020, 30, 889-923.

60. Wachelke, J.; Wolter, R.; Rodrigues Matos, F. Efeito do tamanho da amostra na análise de evocações para representações sociais. Liberabit 2016, 22, 153-160. [CrossRef]

61. Sarubbi Junior, V. Representações Sociais das Equipes Técnicas Acerca do Cuidado à Criança Nas Creches da Universidade de São Paulo. Doctoral Dissertation, Universidade de São Paulo, São Paulo, Brazil, 2013.

62. Vergès, P. L'evocation de l'argent: Une méthode pour la définition du noyau central d'une représentation. Bull. Psychol. 1992, 45, 203-209.

63. Chicarino, V.R.; Jesus, E.F.; Albuquerque, C.V.N.; Aragão Rocha, A.A. Uso de blockchain para privacidade e segurança em internet das coisas. In Livro de Minicursos do VII Simpósio Brasileiro de Segurança da Informação e de Sistemas Computacionais; SBC: Brasília, Brazil, 2017; Volume 28.

64. Bovério, M.A.; Da Silva, V.A.F. Blockchain: Uma tecnologia além da criptomoeda virtual. Rev. Interface Tecnol. 2018, 15, 109-121.

65. Roman, D.P. Como as blockchains Podem Ser Utilizadas Para Gerar Maior Confiança na Asseguração de Dados Ambientais, Sociais e de Governança Corporative. Master's Thesis, FGV /EAESP, São Paulo, Brazil, 2018.

66. Henderson, R.M.; Clark, K.B. Architectural innovation: The reconfiguration of existing product technologies and the failure of established firms. Adm. Sci. Q. 1990, 35, 9-30. [CrossRef]

67. Dannen, C. Bridging the blockchain knowledge gap. In Introducing Ethereum and Solidity; Apress: Berkeley, CA, USA, 2017; pp. 1-20.

68. Catalini, C. How Blockchain applications will move beyond finance. Harv. Bus. Rev. 2017, 2. Available online: https://hbr.org/20 17/03/how-blockchain-applications-will-move-beyond-finance (accessed on 14 December 2021).

69. Carter, L.; Ubacht, J. Blockchain applications in government. In Proceedings of the 19th Annual International Conference on Digital Government Research: Governance in the Data Age, Delft, The Netherlands, 30 May-1 June 2018; pp. 1-2.

70. Oyelere, S.S.; Tomczyk, L.; Bouali, N.; Agbo, F.J. Blockchain technology and gamification-conditions and opportunities for education. In Adult Education 2018-Transformation in the Era of Digitization and Artificial Intelligence; 2019; Available online: https: / / erepo.uef.fi/bitstream/handle/123456789/7905/15785605091238900844.pdf? sequence=2\&isAllowed=y (accessed on 14 December 2021).

71. Friedrich, D.B.; Philippi, J.H.M. Inclusão digital e Blockchain como instrumentos para o desenvolvimento econômico: Digital inclusion and Blockchain as instruments for economic development. Int. J. Digit. Law 2020, 1, 97-116. [CrossRef]

72. Mavilia, R.; Pisani, R. Blockchain and catching-up in developing countries: The case of financial inclusion in Africa. Afr. J. Sci. Technol. Innov. Dev. 2020, 12, 151-163. [CrossRef]

73. Weking, J.; Mandalenakis, M.; Hein, A.; Hermes, S.; Böhm, M.; Krcmar, H. The impact of Blockchain technology on business models-a taxonomy and archetypal patterns. Electron. Mark. 2019, 1-21. [CrossRef]

74. Nowiński, W.; Kozma, M. How can blockchain technology disrupt the existing business models? Entrep. Bus. Econ. Rev. 2017, 5, 173-188. [CrossRef]

75. Morkunas, V.J.; Paschen, J.; Boon, E. How Blockchain technologies impact your business model. Bus. Horiz. 2019, 62, 295-306. [CrossRef]

76. Kant, N. Blockchain: A strategic resource to attain and sustain competitive advantage. Int. J. Innov. Sci. 2021. ahead-of-print. [CrossRef]

77. Han, J. Exploitation of architectural knowledge and innovation. J. Open Innov. Technol. Mark. Co Plexity 2017, 3, 15. [CrossRef]

78. Sujatha, R.; Navaneethan, C.; Kaluri, R.; Prasanna, S. Optimized Digital Transformation in Government Services with Blockchain. Blockchain Technol. Appl. 2020, 79-100. Available online: https://www.sciencegate.app/app/document/download/10.1201/9781 003081487-5 (accessed on 14 December 2021).

79. Kirbac, G.; Tektas, B. The Role of Blockchain Technology in Ensuring Digital Transformation for Businesses: Advantages, Challenges and Application Steps. Multidiscip. Digit. Publ. Inst. Proc. 2021, 74, 17. [CrossRef]

80. Juan, M.D.; Andrés, R.P.; Rafael, P.M.; Gustavo, R.E.; Manuel, P.C. A model for national electronic identity document and authentication mechanism based on blockchain. Int. J. Model. Optim. 2018, 8, 160-165. [CrossRef]

81. Graglia, J.M.; Mellon, C. Blockchain and Property in 2018: At the End of the Beginning. Innov. Technol. Gov. Glob. 2018, 12, 90-116. [CrossRef]

82. Karamitsos, I.; Papadaki, M.; Al Barghuthi, N.B. Design of the blockchain smart contract: A use case for real estate. J. Inf. Secur. 2018, 9, 177. [CrossRef]

83. Kshetri, N.; Voas, J. Blockchain-enabled e-voting. IEEE Softw. 2018, 35, 95-99. [CrossRef] 
84. Xie, J.; Tang, H.; Huang, T.; Yu, F.R.; Xie, R.; Liu, J.; Liu, Y. A survey of blockchain technology applied to smart cities: Research issues and challenges. IEEE Commun. Surv. Tutor. 2019, 21, 2794-2830. [CrossRef]

85. Singh, R.; Dwivedi, A.D.; Srivastava, G. Internet of things based blockchain for temperature monitoring and counterfeit pharmaceutical prevention. Sensors 2020, 20, 3951. [CrossRef]

86. Pelt, R.V.; Jansen, S.; Baars, D.; Overbeek, S. Defining blockchain governance: A framework for analysis and comparison. Inf. Syst. Manag. 2021, 38, 21-41. [CrossRef]

87. Lacity, M.C. Addressing Key Challenges to Making Enterprise Blockchain Applications a Reality. MIS Q. Exec. 2018, 17, 201-222

88. Rikken, O.; Janssen, M.; Kwee, Z. Governance challenges of blockchain and decentralized autonomous organizations. Inf. Polity 2019, 24, 397-417. [CrossRef]

89. Priem, R.L.; Butler, J.E. Tautology in the resource-based view and the implications of externally determined resource value: Further comments. Acad. Manag. Rev. 2001, 26, 57-66. [CrossRef]

90. Eisenhardt, K.M. Better stories and better constructs: The case for rigor and comparative logic. Acad. Manag. Rev. 1991, 16, 620-627. [CrossRef]

91. Sumpter, D.M.; Greenberg, D.; Kim, S. The dark side of construct convergence: Navigating consensus, evolution, and practical relevance in theory building. Acad. Manag. Perspect. 2021, 35, 485-502, in press. [CrossRef] 